\title{
Legislative Oversights and Budget Performance in Nigeria: Issues \& Policy Options
}

\author{
Ehigiamusoe, Uyi Kizito ${ }^{1}$ \& Umar, Aminu ${ }^{2}$ \\ National Institute for Legislative Studies, National Assembly, Abuja, Nigeria
}

\begin{abstract}
Budget implementation in Nigeria has been a burning issue since the advent of democracy in 1999. Several reasons have been adduced for the poor performance of federal government capital budgets. These include late presentation, passage, and assent to the budget; late release of funds to and poor capacity utilization of Federal Ministries, Departments and Agencies (MDAs). But much attention has not been given to the role of legislative oversights in this regards. Consequently, this paper examines the role of legislative oversights in budget performance. Using survey method, descriptive statistics and analytical approach, the paper analyzed both primary and secondary data. The findings of the study revealed that oversight activities have increased tremendously in Nigeria since 1999, but they have not been very effective in reducing corruption and accelerating budget performance of MDAs. The paper therefore recommended policy options on how to utilize legislative oversight activities as instruments for promoting targeted budget outcomes.
\end{abstract}

Keywords: Legislative Oversights; Budget Performance; Ministries, Department and Agencies (MDAs); Corruption; Public Finance.

\section{Introduction}

The international financial institutions are particularly keen to promote greater transparency in public finance management after the Asian financial crisis in the late 1990s had revealed the structural weaknesses of financial information systems in emerging economies (Santiso \& Belgrano 2004). Enhancing the contribution of the legislature to budget oversight is increasingly considered as a means of strengthening government accountability and curb corruption in public finance management (OECD 2002). The first-wave of reforms in government financial management in the late 1980s and early 1990s have focused on improving governmental financial administration and promoting greater transparency and efficiency in public finance management (Dorotinsky \& Matsuda 2002). In the course of the 1990s, most Latin American countries have undertaken significant efforts to upgrade their public finance management and information systems (Dorotinsky \& Matsuda 2002). However, less attention has been paid to the simultaneous need to strengthen the mechanisms of accountability, restraint and integrity in budget management. The experience of Peru in the 1990s clearly shows the limits of expeditious decision-making and the consequent need to strengthen the mechanisms of horizontal accountability (See Mainwaring \& Welna 2003; Schedler 1999 and O’Donnell 1998).

The second wave of reforms currently underway is emphasizing the concurrent need to strengthen integrity and accountability in economic governance and public finance management. However, what explains the effectiveness of parliaments in budget, policy-making and oversight in emerging economies remains largely under-theorized. The Latin American experience also demonstrated that excessive executive discretion in budget execution is equally perilous. When executive discretion in public budgeting is not adequately balanced with effective mechanisms of internal restraint and external accountability, the abuse and misuse of budget authority are more likely to occur. A key challenge the governance of the budget in emerging economies resides in the ability of emerging institutional arrangements to adequately combine political accountability and fiscal prudence (Wehner 2003; Santiso and Belgrano 2004).

The presidential system of government practiced in Nigeria makes provision for separation of powers, apportioning disparate powers and duties to the three arms of government namely; the executive, legislature and judiciary. Essentially, the legislature makes laws which the executive is under obligation to implement. The judiciary is called upon in the determination of civil rights and obligations to interpret the laws. The presidential system of government understands that powers may be abused and therefore introduced a system of checks and balances among the three arms of government. The legislature has the power of oversight over the execution and

\footnotetext{
${ }^{1}$ Ehigiamusoe, Uyi Kizito is a Research Economist at the Research Division, National Institute for Legislative Studies, National Assembly, Abuja, Nigeria

${ }^{2}$ Umar, Aminu is a Research Fellow at the Research Division, National Institute for Legislative Studies, National Assembly, Abuja, Nigeria. The views expressed in the paper are those of the authors and do not in any way represent the views or thinking of the National Institute for Legislative Studies
} 
administration of laws by the executive. The executive holds the powers of investigation, coercion and implementation of laws and can as well use these powers to call the legislature and judiciary to account (Onyekpere 2012). Thus, it is a system created for the overall benefit of the citizens

Legislative oversight refers to the review, monitoring, and supervision of the executive arm of government, including the numerous Federal Ministries, Departments and Agencies (MDAs)'s programs, activities, and policy implementation by the National Assembly. The legislature exercises this power largely through its legislative committee system. Legislative oversight authority derives from its "implied" powers in the Constitution, and House \& Senate rules. It is an integral part of the Nigerian system of checks and balances. Oversight as an outgrowth of this principle serves a number of overlapping objectives and purposes such as improvement in the efficiency, economy, and effectiveness of governmental operations; evaluation of programs and performance; detection and prevention of poor administration, waste, abuse, arbitrary and capricious behaviour, or illegal and unconstitutional conduct etc

Since the return to civil rule in 1999 in Nigeria, the federal capital budgets have been poorly implemented by the executive. Hardly has capital budget implementation risen above 50 per cent at the end of the fiscal year. When this fact is juxtaposed against the background that the recurrent part of the budget has been consuming about 70 per cent of the budget, then the implication is that Nigeria has been dedicating about 15 per cent of the overall annual budget to capital expenditure (Onyekpere 2012). This has led to poor social indicators, infrastructural deficit, poverty massive unemployment and underdevelopment. What is the role of the legislature in all of these? This is where the power of oversight vested in the National Assembly by Sections 88 and 89 of the 1999 Constitution as amended should be utilized (Onyekpere 2012).

By Section 88 of the Constitution, the National Assembly is empowered to conduct investigations into any matter or thing with respect to which it has power to make laws. It also has power to conduct investigations into the conduct or affairs of any person, authority, ministry or government department charged, or intended to be charged with the duty or responsibility of executing or administering laws enacted by it and the disbursement or administration of funds appropriated or to be appropriated by the lawmakers. These powers are meant inter alia to correct defects in existing laws and for the enactment of new laws, expose corruption, inefficiency or waste in the system or disbursement of money appropriated by the legislature. By Section 89, the National Assembly has powers to procure evidence needed for the investigation, require evidence to be given on oath, compel the attendance of witnesses on the pain of punishment if they fail to attend, etc.

Analysts have argued that legislative oversight committees have not been very effective in stimulating MDAs to the attainment of budget outcomes. They argued that some legislative committees use oversight activities to intimidate rather than to encourage Ministries, Departments and Agencies (MDAs) to perform at optimum levels especially in the areas of budget implementation. The analysts raised the issues of transparency and accountability as well as the resources expended in oversight activities when juxtaposed with the benefits of such investigations. These, among other things, made them to arrive at the conclusion that oversights activities have not been very beneficial to Nigeria. On the other hand, another school of thought believed that legislative oversights help to accelerate the performance of many Ministries, Departments and Agencies (MDAs) in Nigeria. They contended that oversight functions serve as checks and balances on the activities of the executive arm of government, including Federal MDAs and therefore help to promote their overall performance. As the debate on the efficacy of legislative oversight continues, it becomes imperative to empirically examine the relationship between legislative oversights and budget performance of MDAs in Nigeria. The broad objective of this study is to examine the role of legislative oversights in budget performance in Nigeria. Specifically, the study seeks to analyze the issues and challenges of legislative oversights in Nigeria and proffers policy options for Nigeria on how to effectively utilize legislative oversights to enhance budget performance.

Following this introduction, the remaining part of the paper is divided into four parts. Section two presents the conceptual and empirical issues. Section three contains the methodology adopted in the study, while section four presents the findings and policy implications of the study. Section five contains the policy options, recommendations and conclusion.

\section{Conceptual And Empirical Issues}

\subsection{Legislative Oversight and Ministries, Departments and Agencies (MDAs)}

Legislative oversight refers to the legislature's review and evaluation of selected activities of the executive branch of government. The legislative branch conducts oversight activities because it has not only the power to enacts new programs for the state, but also has a duty to ensure that existing programs are implemented and administered efficiently, effectively, and in a manner consistent with legislative intent. While oversight is one of the major focuses of legislative committees, it is an integral part of the legislative process that is often difficult to separate from the law-making process. Oversight is the focus of some selected committees and special oversight committees and can also be part of the hearings and work of standing committees (Stair-Hall 2011). 
According to Stair-Hall (2011), the budget process includes many oversight activities, because during the annual appropriation process, the National Assembly must relate the overall value of a program to other programs competing for funding from limited state resources. To some extent, legislature determine relative funding levels for programs on the basis of information they receive by questioning executive branch's administrators during budget hearings. Oversight as an outgrowth of this principle serves a number of overlapping objectives and purposes which include;

- Improvement in the efficiency, economy, and effectiveness of governmental operations;

- Evaluation of programs and performance;

- Detection and prevention of poor administration, waste, abuse, arbitrary and capricious behaviour, or illegal and unconstitutional conduct;

- Protection of civil liberties and constitutional rights;

- Informing the general public and ensuring that executive policies reflect public interest;

- Gathering information to develop new legislative proposals or to amend existing statutes;

- Ensuring administrative compliance with legislative intent; and

- Prevention of executive encroachment on legislative authority and prerogatives (See Wikipedia).

Writing on the role of parliamentary committees, Stapenhurst (2012) submitted that legislative committees are the engine rooms of the Legislature, and where the committee system is underdeveloped, the budgetary role of the legislature tends to be weak. Pelizzo and Stapenhurst, (2008) asserted that specialized committees have emerged as fundamental tools for oversight in general and for the budget process and spending of public monies in particular. In many parliaments, the Public Accounts Committee (PAC) serves as the audit committee of parliament, making it a core institution of public financial accountability. Anderson (2008) noted that effective oversight committees are most often those with supportive staff, useful partners, and allies from the bureaucracy and civil society. Legislatures and their committees are often assisted in their oversight function by extra parliamentary accountability institutions, such as supreme audit institutions and ombudsmen. Parliamentary budget office may also provide independent expertise and support to parliament. The author stressed the potential value of such independent analytical budget units in putting the legislature on a more equal footing with the executive and in increasing the overall transparency, credibility, and accountability of the budget process and such units must be nonpartisan, independent, and objective to successfully fulfill their core functions (Anderson 2008).

In the $7^{\text {th }}$ Nigeria's National Assembly, there are 56 standing committees in the Senate and 90 standing committees in the House of Representatives, most of which perform oversight functions.

It is a common knowledge that corruption is prevalent in the administration of Ministries, Departments and Agencies (MDAs) in Nigeria. But what is worrisome is the inability of parliament to address this cankerworm that is eating deep into the fabrics of our society. If corruption is the bane of budget performance in MDAs, it is expected that the parliament through oversights should examine the activities of these MDAs with a view to unravelling the corrupt practices that are militating against budget outcomes. To this effect, the Amended 1999 Constitution of the Federal Republic of Nigeria granted the power of investigation to the parliament in sections 88 and 89 of the constitution.

The executive has responsibility for drafting and implementing the budget while the role of parliament is to check that this responsibility is successfully fulfilled. Warren \& Joachim, (2004) noted that the parliament can assist government Departments and Agencies to plan and implement budgets more effectively and efficiently and in the process help to curb corruption, reduce the gaps between planned and actual budgets, and engender greater efficiency in Departmental spending. Corroborating this view, Santiso \& Belgrano, (2004) opined that the role of parliaments in public budgeting is currently being re-evaluated and the re-discovery of legislative budget institutions in emerging economies is partly due to the need to ensure government accountability in the management of public finances, counterbalance executive discretion in budgeting and curb corruption. Similarly, Langdon, (2012) asserted that public accounts committees have been especially crucial in evaluating the effectiveness of programs, checking out financial probity and initiating sanctions against corruption. Through oversight functions, the parliament in Nigeria can expose corruption and corrupt practices in MDAs with a view to initiating sanctions against them through anti graft agencies such as Economic and Financial Crime Commission (EFCC), Independent Corrupt Practices and other related offences Commission (ICPC), the Nigerian Police Force and the Judiciary.

\subsection{Empirical Issues}

According to Lienert, (2009), out of the three core functions of the legislature namely representation, law-making, and oversight, the oversight function is perhaps the least studied and practiced. Legislative oversight involves examining fidelity to budget laws, probity in spending, efficiency in choices, and the effectiveness of the budget in producing the desired outcomes. In many countries, oversight provides the opportunity for legislators to participate in implementation and when it comes to budgeting, evaluation is 
needed to assess how well policies have been implemented (Lienert 2009). The analysis of the authors reveals that legislatures in parliamentary systems are generally better equipped to oversee government activities than legislatures in presidential systems. In the budget process of presidential systems, legislatures are generally the most active in the preparation of the budget, whereas legislatures in parliamentary systems are the most active in approving the budget.

Warren \& Joachim, (2004) noted that parliament's 'power of the purse' is a fundamental feature of democracy. The vast majority of democratic constitutions require appropriations and taxation measures to be approved by parliament in order to become effective, and as a result, parliament must ensure that the revenue and spending measures it authorizes are fiscally sound, match the needs of the population with available resources, and are implemented properly and efficiently. They further asserted that stronger parliamentary budget oversight has many supporters and detractors. On the positive side, it is argued that effective parliamentary oversight of public budgets is central to democratization and improved budget management because the parliament has a role to ensure that the nation's priorities are adequately reflected in the nation's major fiscal plan - the budget. Nevertheless, it is argued that parliament usually does not have sufficient information or technical capacity to play an effective role in the budget process. The executive will always have a greater information base than the legislature, and the parliament will enter the process at a later stage. Moreover, most parliamentary committees in developing and transitional countries do not have sufficient technical research, or even administrative capacity to conduct oversight functions (See Warren \& Joachim 2004).

Commenting on the challenges facing legislative oversight, Santiso \& Belgrano, (2004) submitted that one of the greatest challenges remains to strengthen democratic accountability while ensuring fiscal discipline. They further revealed that there has been increased legislative activism in public budgeting in recent years after decades of rocked executive-legislative relations since the restoration of democracy. They nevertheless argued that the contribution of the legislature to budget oversight remains inhibited by structural factors, both internal and external to legislative organisation. Effective legislative budgeting requires the capacity to discharge budgetary functions effectively and responsibly, as well as the existence of an enabling environment. Ultimately, the governance of the budget reflects a delicate balance between executive power and legislative oversight whose effectiveness is largely determined by the broader governance context of budget policy-making (Santiso \& Belgrano 2004).

Langdon, (2012) noted that one crucial challenge which parliaments face is how their increased influence can contribute to governance improvements and overwhelming policy priority of countering poverty. The basis of its thrust is the experience emerging in various parliaments that suggests that effective oversight can greatly increase social accountability of governments, and thereby contribute to a significant result from poverty reduction policy goals.

In his submission on the challenges of parliaments to accelerate poverty reduction through financial oversight, Langdon, (2012) noted that there are those who would seriously question such a possibility and it is common to hear major objections to a significant parliamentary role in economic policy making. Firstly, parliamentarians lack the technical expertise to be able to participate in economic planning and analysis, and therefore cannot be expected to be real players in the financial policy process. Secondly, parliamentarians are pushed by the pressures of local constituency interests and will seek to increase spending in their areas -- thus accelerating spending in general and distorting overall budgets. Thirdly, parliaments are too subject to political party dominance that prevents the exercise of significant oversight responsibilities on the executive, and can make members of parliaments subservient to partisan priorities in analysing resource allocation and service delivery issues (Langdon 2012).

Onyekpere, (2013) observed that oversight visits and investigations are not ends in themselves. It will be unproductive and wasteful of public resources if no follow-up remedial action is founded on them. The challenge to the National Assembly is to put their budget monitoring reports with well-researched recommendations in the public domain with a view to gaining public support. Similarly, Obayuwana, (2012) noted that legislative oversight the world over is largely seen as the process by which a legislative body takes an active role in understanding and monitoring the performance of the executive arm and apply this knowledge to its other primary functions. The legislature has to know and understand the operations of the executive branch in order to make informed decisions on the laws which it passes and the financial decisions which it makes. The author asserted further that legislative oversight provides a powerful check on the executive authority, enhancing accountability where a dominant executive branch might otherwise operate with impunity and noted that the primary objective of legislative oversight is to detect problems and deficiencies in the delivery of government services.

According to Stair-Hall, (2012) Legislative oversight is the specific focus of some legislative activities and it is an integral part of the legislative process that is often difficult to separate from the lawmaking process. The most direct and formal oversight functions are carried out by special or select committees that the National 
Assembly has created to review very specific and narrowly define issues. These committees may consist exclusively of legislators or they may include legislators as part of a broader committee membership.

In the words of the Public Accounts Committee of the New South Wales Australia, the Parliament is the centre of the accountability of the public sector and that it is through its accountability to the parliament that the public sector is ultimately accountable to the people. Hubbard, (2012) noted that despite the great deal of talk about transparency and accountability, parliamentary oversight remains more an idea than a reality. He asserted that if parliamentary oversight is to be truly effective, parliamentary best practices must be identified and implemented. This means that oversight committees must have true independence in the pursuit of transparency and accountability, clear and expansive powers to conduct necessary investigations, support from political leadership, meaningful inclusion of the opposition parties, adequate resources for oversight bodies, and strong links to other relevant agencies. Political interference and lack of resources in particular, have hampered parliamentary oversight in other Commonwealth states. He stated further the need to include non-parliamentary oversight bodies like the Ombudsman and the Auditor General, as well as civil society, to work with the Government to improve transparency and accountability (Hubbard 2012).

Corder, (1999) noted that accountability now means more than financial accountability because it means accountability in the wider sense, openness as well as responsiveness where the executive must account on a wide range of issues and may be called to justify its actions. National Assembly must provide for mechanisms to ensure executive organs are accountable and to maintain oversight of these organs.

Williams, (2012) asserted that parliamentary oversight function is one of the cornerstones of democracy. Oversight is a means for holding the executive accountable for its actions and for ensuring that it implements policies in an effective manner. The robust monitoring of the executive by the parliament is an indicator of good governance. Besides the parliament's legislative function, it is through oversight that the parliament can ensure a balance of power and assert its role as the defender of people's interests. According to him parliamentarians conduct oversight in order to ensure transparency and openness of executive activities; hold the executive branch accountable; provide financial accountability; and uphold the rule of law. Williams (2012) therefore, identified the most common tools and mechanisms used by the parliament to conduct oversight to include: questions to ministers (oral and written), interpellation, and votes of no confidence. Other tools include mechanisms related to budgetary oversight, impeachment, and the possibility for the parliament to establish ad-hoc committees, commissions of enquiry or an ombudsman's office. The author stressed the need to strengthen the oversight function of parliament through parliament's institutional and legal framework to encourage parliament to make effective use of their powers of oversight. Aside from the provision of oversight tools, this framework should provide for the independence of the parliamentary institution and the immunity of the MPs. These protections allow Parliament to challenge the executive without fear of retaliation against their person. The parliament's legal framework should also include rights, such as access to information, that give them the capacity to conduct inquiries that reach the heart of the government (Williams 2012).

Langdon, (2012) added that the most important ongoing instruments of effective parliamentary action on financial policy have been parliamentary committees and that finance or budget committees have been especially important with respect to budget planning, to reviewing budget allocation details and to pursuing financial reporting goals. He noted that scrutiny of specific spending and revenue details in themselves are not sufficient areas where Parliaments should concentrate in working for the poor in the financial oversight context. The author further identified four fundamental poverty reduction priorities that should also preoccupy parliaments in many countries to include: participation of the poor; public service implementation effectiveness; policy impact review and poverty monitoring; and macro-economic management.

\section{Methodology}

The study adopts a survey method using both primary and secondary data. The population of the study included all Federal Ministries, Departments and Agencies (MDAs) and all oversight committees in the National Assembly in Nigeria. Simple random sampling technique was adopted to select the MDAs and oversight committees for the study. Fifty (50) Federal Ministries, Departments and Agencies (MDAs) and fifty (50) oversight committees were selected for the fieldwork. The MDAs were selected based on two considerations namely; their sizes and those MDAs where issues of fiscal/economic relations have become especially controversial and volatile in recent times. Primary data were sourced through a survey method involving the use of in-depth interviews and structured questionnaires. Secondary data were derived from Central Bank of Nigeria (CBN) Statistical Bulletins, National Bureau of Statistics (NBS), and the Office of the Accountant General of the Federation (OAGF). The data gathered from the use of questionnaires and interviews on the role of legislative oversights on budget performance were analyzed using descriptive statistics and analytical approaches, while the secondary data on budget performance were analyzed using simple percentages.

\section{Data Analysis And Presentation Of Results}


Available data from the Central Bank of Nigeria (CBN) reveal the total, recurrent and capital expenditures of the federal government of Nigeria from 1999-2012. The country's total expenditure for the period stood at N32, 432,489.68 million. A breakdown of the figure shows that recurrent expenditure accounted for N22, 073,767.38 million while capital expenditure accounted for N 9,345,618.10 million (See table 1). Further analysis shows that recurrent expenditure as a percentage of total expenditure averaged $62 \%$ for the period, while capital expenditure as a percentage of total expenditure averaged $31 \%$ during the period under review. This analysis further confirmed the fact that government expenditure had been dominated by recurrent expenditure since the advent of democracy in the fourth Republic in Nigeria.

Table 1: The Expenditures of the Federal Government of Nigeria from 1999-2012 (N' million)

\begin{tabular}{|l|l|l|l|l|l|}
\hline Year & Total Expenditure & $\begin{array}{l}\text { Recurrent } \\
\text { Expenditure }\end{array}$ & $\begin{array}{l}\text { Recurrent Exp as \% } \\
\text { of Total Exp }\end{array}$ & $\begin{array}{l}\text { Capital } \\
\text { Expenditure }\end{array}$ & $\begin{array}{l}\text { Capital Exp as \% } \\
\text { of Total Exp }\end{array}$ \\
\hline 1999 & $947,690.00$ & $449,662.40$ & 47.44 & $498,027.60$ & 52.54 \\
\hline 2000 & $701,059.40$ & $461,600.00$ & 65.84 & $239,450.90$ & 34.16 \\
\hline 2001 & $1,018,025.60$ & $579,300.00$ & 56.90 & $438,696.50$ & 43.09 \\
\hline 2002 & $1,018,155.80$ & $696,800.00$ & 68.44 & $321,378.10$ & 31.56 \\
\hline 2003 & $1,225,965.90$ & $984,300.00$ & 80.29 & $241,688.30$ & 19.71 \\
\hline 2004 & $1,426,200.00$ & $1,032,700.00$ & 72.41 & $351,300.00$ & 24.63 \\
\hline 2005 & $1,822,100.00$ & $1,223,700.00$ & 67.16 & $519,500.00$ & 28.51 \\
\hline 2006 & $1,938,002.50$ & $1,290,201.90$ & 66.57 & $552,385.80$ & 28.50 \\
\hline 2007 & $2,450,896.70$ & $1,589,270.00$ & 64.84 & $759,323.00$ & 30.98 \\
\hline 2008 & $3,240,820.00$ & $2,117,362.00$ & 65.33 & $1,123,458.00$ & 34.61 \\
\hline 2009 & $3,452,990.80$ & $2,300,194.30$ & 66.61 & $1,152,796.50$ & 33.39 \\
\hline 2010 & $4,194,217.88$ & $3,310,343.38$ & 78.93 & $883,874.50$ & 21.07 \\
\hline 2011 & $4,299,155.10$ & $3,054,333.40$ & 71.04 & $918,548.90$ & 21.37 \\
\hline 2012 & $4,697,210.00$ & $2,984,000.00$ & 63.53 & $1,345,190.0$ & 28.64 \\
\hline Total & $\mathbf{3 2 , 4 3 2 , 4 8 9 . 6 8}$ & $\mathbf{2 2 , 0 7 3 , 7 6 7 . 3 8}$ & $\mathbf{6 8 . 0 6}$ & $\mathbf{9 , 3 4 5 , 6 1 8 . 1 0}$ & $\mathbf{2 8 . 8}$ \\
\hline
\end{tabular}

Sources: CBN Statistical Bulletin 2011, 2012 Budget Document and Budget Review

Despite spending over N32 trillion in the past 14 years, Nigeria is still characterised by high rate of poverty, unemployment, income inequality, infant and maternal mortality and decay in infrastructure. The country still suffers from inadequate supply of electricity, water, housing, health, transport and educational facilities. One of the possible explanations advanced for the poor state of infrastructure in Nigeria is poor budget implementation by Ministries, Departments and Agencies (MDAs). It has also been advocated that the poor nature of budget performance in Nigeria since the advent of democracy in 1999 is ineffective oversight functions by the legislative arm of government. Though corruption could also be seen as one of the major factors responsible for the implementation status of the federal government budget, but indications are that corrupt practices preponderance in public offices in the country is as a result of weak oversight function by the parliament who are supposed to act as checks and balances on the activities of the executive arm of government. Though, the National Assembly has exposed monumental corruption in the Power and Oil sectors of Nigeria, but the lack of commitment to ensure the struggle is pushed beyond the exposure seriously hinders the eradication of the scourge in our society.

Figure 1 shows the expenditures of the federal government of Nigeria from 1999-2012. A further analysis of the capital expenditure component of the aggregate expenditure shows that despite the low percentage of capital expenditure as a proportion of total expenditure in the budget, the implementation level of capital projects in the country had been abysmal. 
Figure 1: The Expenditures of the Federal Government of Nigeria from 1999-2012 (\%)

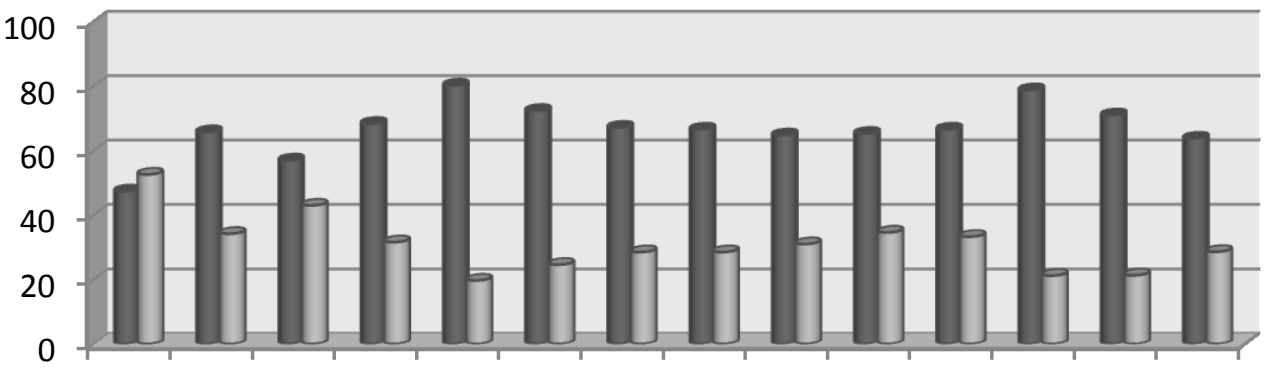

19992000200120022003200420052006200720082009201020112012

Recurrent Expenditure as a percentage of Total Expenditure

$\square$ Capital Expenditure as a percentage of Total Expenditure

Source: Authors' computation

\subsection{Legislative Oversights and Capital Projects Implementation in Nigeria}

The Federal Government capital budgets have been poorly implemented by the executive since the advent of democracy in the Fourth Republic. Even though the recurrent-capital expenditure ratio has always been in the neighborhood of $70 \%$ to $30 \%$, the capital budgets have always witnessed abysmal performance at the end of the fiscal year. Onyekpere, (2013) submitted that since 1999, hardly has capital budget implementation risen above 50 per cent at the end of the fiscal year. The implications of this are poor social indicators, infrastructural deficit, mass unemployment and high rate of poverty and underdevelopment.

The role of the legislature in all of these is to ensure through oversights that MDAs utilize the funds allocated to them efficiently and effectively with a view to preventing reckless spending, diversion and mismanagement of public funds. For instance, the 2012 capital budget implementation was only $25 \%$ as at September. At the end of the year in December only about $50 \%$ of the capital budget was implemented. The poor performance of capital budgets in Nigeria over the years is a function of multi-dimensional variables among which is corruption which is supposed to be checked by effective legislative oversights. It is important to note that the National Assembly is empowered to conduct investigations into any matter or thing with respect to which it has power to make laws. It also has power to conduct investigations into the conduct or affairs of any person, authority, ministry or government department charged, or intended to be charged with the duty or responsibility of executing or administering laws enacted by it and the disbursement or administration of funds appropriated or to be appropriated by the lawmakers. These powers are meant inter alia to correct defects in existing laws and for the enactment of new laws, expose corruption, inefficiency or waste in the system and waste in the administration or disbursement of moneys appropriated by the legislature (See Section 88 of the 1999 Constitution). Table 2 shows the Capital Expenditure Performance of MDAs as at December 31 st, 2012.

Table 2: Capital Expenditure Performance of MDAs as at December 31st, 2012 (N’ Billion).

\begin{tabular}{|l|l|l|l|l|l|l|l|}
\hline MDAs & $\begin{array}{l}2012 \\
\text { Budgeted }\end{array}$ & $\begin{array}{l}\text { Actual } \\
\text { Releases }\end{array}$ & Released & $\begin{array}{l}\text { Amount } \\
\text { Cashed- } \\
\text { Back }\end{array}$ & $\begin{array}{l}\text { MDAs } \\
\text { Balance.@ } \\
\text { Dec.31 }\end{array}$ & $\begin{array}{l}\text { Amount } \\
\text { Utilized } \\
\text { Utilized }\end{array}$ \\
\hline Presidency & 15.66 & 13.57 & 86.7 & 12.02 & 0.29 & 11.73 & 74.9 \\
\hline SGF & 32.73 & 21.82 & 66.7 & 16.23 & 5.56 & 10.67 & 32.6 \\
\hline Youth Devt & 7.15 & 4.35 & 60.8 & 3.33 & 0.36 & 3.32 & 46.4 \\
\hline Agriculture & 48.19 & 32.47 & 67.4 & 26.4 & 0.25 & 26.14 & 54.2 \\
\hline Water Resources & 79.33 & 55.56 & 70.0 & 39.76 & 0.54 & 39.22 & 49.4 \\
\hline Defence & 45.44 & 37.49 & 82.5 & 37.49 & 3.16 & 34.33 & 75.5 \\
\hline Education & 66.83 & 47.59 & 71.2 & 36.46 & 1.62 & 34.83 & 52.1 \\
\hline Health & 60.95 & 45.00 & 73.8 & 37.17 & 3.49 & 33.68 & 55.3 \\
\hline
\end{tabular}


Legislative Oversights and Budget Performance in Nigeria: Issues \& Policy Options

\begin{tabular}{|l|l|l|l|l|l|l|l|}
\hline Power & 75.49 & 52.03 & 68.9 & 41.10 & 1.55 & 39.55 \\
\hline Works & 159.46 & 125.57 & 78.7 & 125.43 & 14.08 & 125.29 & 99.8 \\
\hline Transport & 46.86 & 31.51 & 67.2 & 26.94 & 2.92 & 24.02 & 51.5 \\
\hline Mines \& Steel & 3.17 & 1.98 & 62.5 & 1.50 & 0.37 & 1.47 & 46.4 \\
\hline Aviation & 43.16 & 33.10 & 76.7 & 31.01 & 0,59 & 30.95 & 71.7 \\
\hline FCTA & 46.26 & 35.53 & 76.8 & 33.37 & 0.14 & 33.36 & 72.1 \\
\hline Foreign Affairs & 7.45 & 5.99 & 80.4 & 5.28 & 0.43 & 5.23 & 70.2 \\
\hline Interior & 7.56 & 5.12 & 67.7 & 4.21 & 0.10 & 4.2 & 55.5 \\
\hline Petroleum & 8.13 & 5.29 & 65.1 & 3.98 & 2.25 & 1.73 & 76.9 \\
\hline Science \& Tech & 27.31 & 18.57 & 67.9 & 13.15 & 0.76 & 13.07 & 47.9 \\
\hline Others & 642.71 & 320.19 & 49.8 & 245.17 & 14.54 & 213.44 & 33.2 \\
\hline Grand Total & $1,345.19$ & 1,017 & 75.6 & 739.3 & 53.0 & 686.3 & 51.0 \\
\hline
\end{tabular}

Source: Office of the Accountant General of the Federation (OAGF). A Review of 2013 Appropriation Bill of the Federal Government of Nigeria by NILS

Table 2 presents the detailed capital budget performance of MDAs as at December $31^{\text {st }} 2012$. A total of $\mathrm{N} 1,017$ billion (representing 75.6\%) was released against N1, 345 billion appropriated in the budget. Out of the total capital budget released, N686.3 billion (representing $51 \%$ ) was utilized. The amount cashed back during the period was N739.3 billion, while N53 billion was MDAs Balance. However, the detailed capital budget performance of MDAs, as measured by the ratio of utilization to amount cash-backed of total releases was relatively unsatisfactory. On the average, the ratio of capital utilization performance to amount cash-backed of total releases was $51 \%$. Despite the fact that only about $25 \%$ of the capital budget was yet to be released as at December $31^{\text {st }}, 2012$, about half of the capital funds released for 2012 were not utilized by MDAs. Therefore, the capital budget performance measured as the ratio of cash utilization by MDAs to the total 2012 appropriation was poor. The main reasons which accounted for the poor performance of capital budget in 2012 include; non-release of adequate capital funds to MDAs, late release of funds to MDAs and non-utilization of released funds by MDAs. These factors can be minimized or eliminated by effective oversight functions by the parliament.

The performance of MDAs in terms of capital funds releases and utilization is mixed because some MDAs performed creditably well in relation to their releases, while others performed poorly. For instance, table 1 reveals the MDAs that recorded the highest percentage of capital budget releases. The Presidency recorded the highest percentage of capital budget releases of $86.7 \%$ followed by Defence (82.5\%), Foreign Affairs $(80.4 \%)$, Works (78.7\%), FCTA (76.8\%), Aviation (76.7\%), and Health (73.8\%). The MDAs that recorded the lowest percentage of capital releases include; Youth Development (60.8\%), Housing (64.6\%), Petroleum $(65.1 \%)$, Transport (67.2\%), and Science \& Technology (67.9\%), In terms of funds utilization, Works, Defence and Petroleum recorded $99.8 \%, 76.9 \%$ and $75.5 \%$, respectively, to come tops, while the MDAs that recorded the lowest include; ICPC (33.8\%), Trade \& Investment (42.3\%), Labour \& Productivity (44.9\%), Women Affairs (46.5\%), Mines \& Steel (46.4\%), Justice (47.9\%) and Science \& Technology (47.9\%). Figure 2 shows the 2012 Budgeted, Actual and Utilized funds.

Figure 2: Capita Budget Utilization Level as at December, 2012 ( $\mathrm{N}$ billion) 


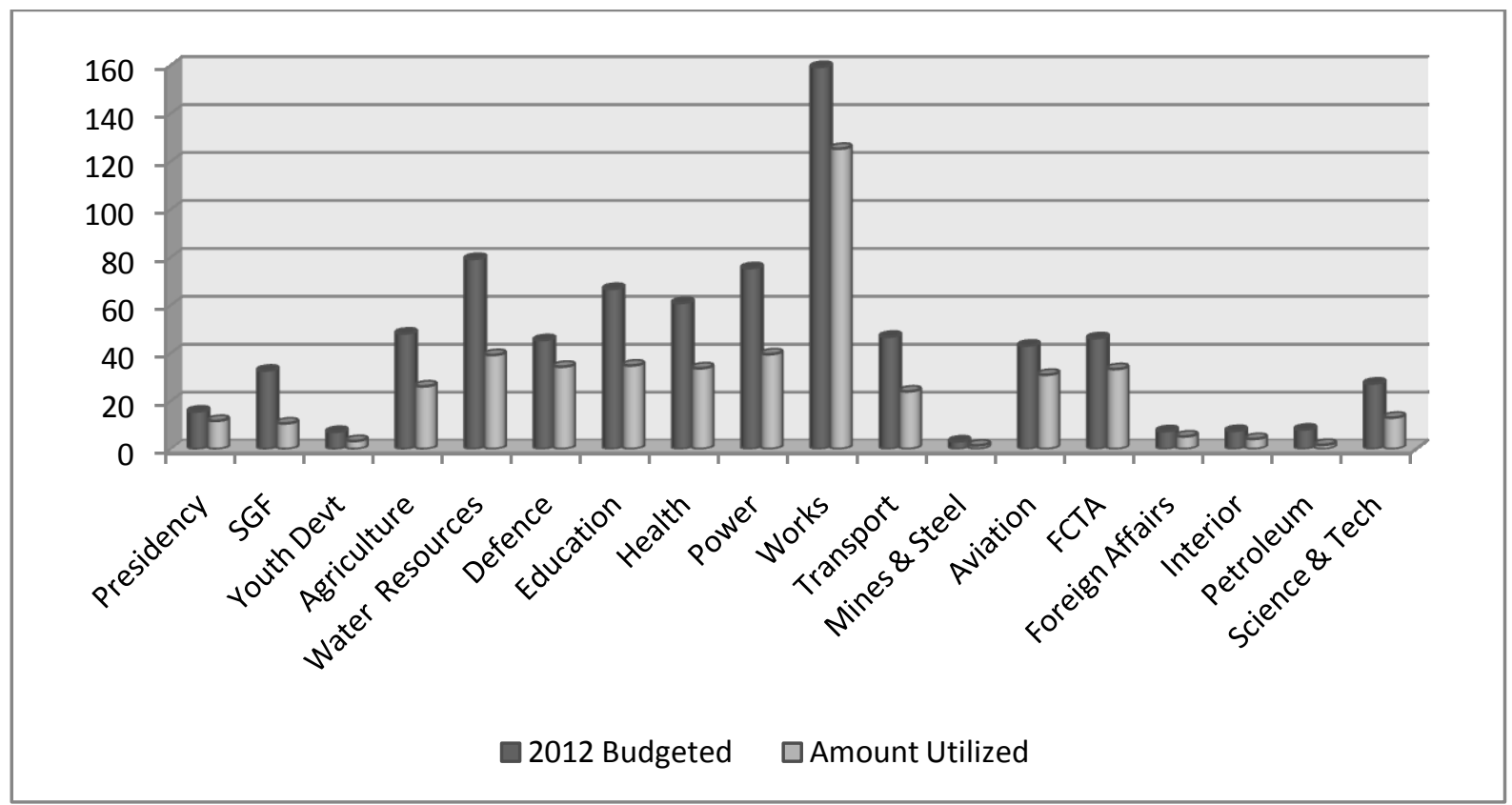

Source: Authors' computation

Nakamura, (2008) submitted that the problem of budget implementation in Nigeria is that Nigerians are not receiving value for money spent when programs are not implemented by the executive (large sums are returned to the treasury because of the inability to spend the funds), resources are diverted through corruption, inefficient choices are made, and so many of the outcomes they seek worsen even as spending increases. Figure 3 shows the percentage of capital funds utilization in Nigeria in 2012.

Figure 3: Capita Budget Utilization Level as at December, 2012 (Percentage)

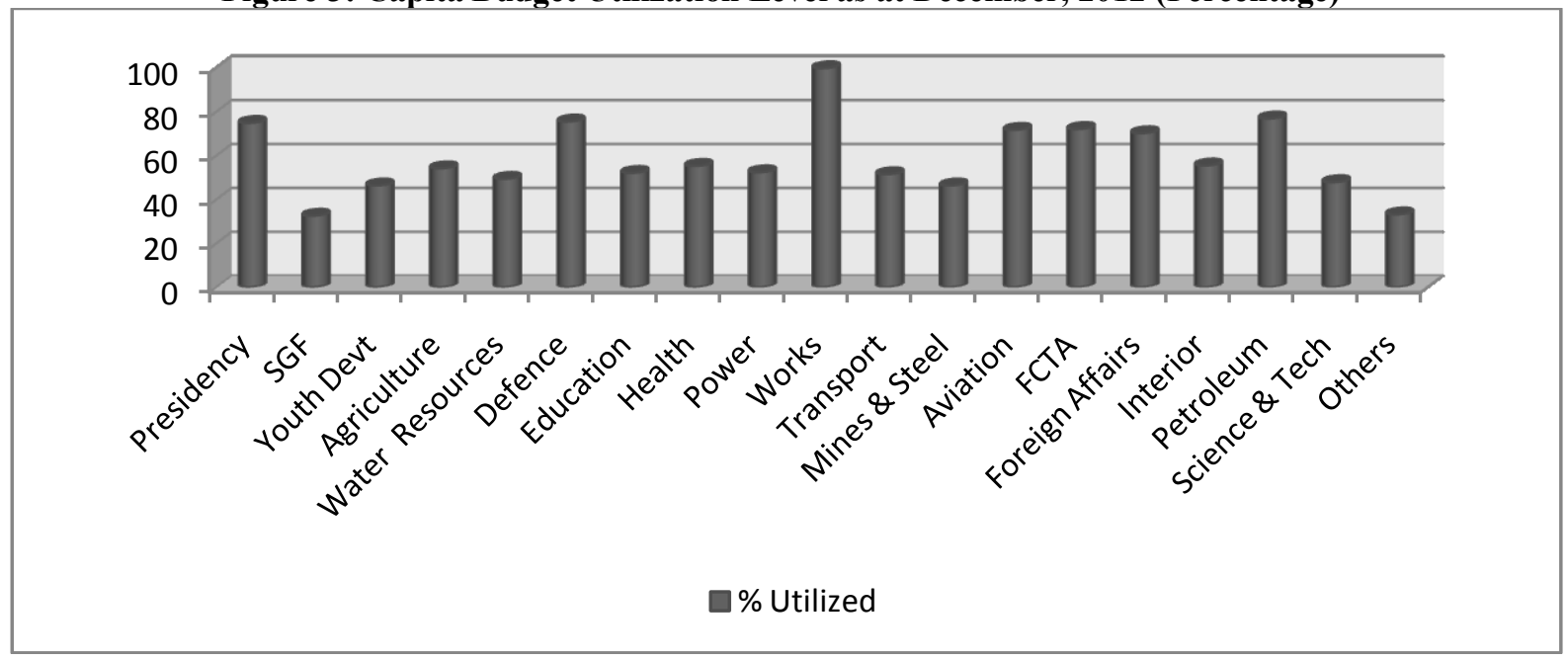

Source: Authors' computation

\subsection{Responses from Respondents on the Relationship between Oversights and Budget Performance}

The responses from the respondents revealed that most oversight committees conduct oversights on MDAs under their supervision annually. $90 \%$ of the respondents interviewed agreed that their supervising committees conduct oversight on them every year. This shows that these committees are committed to their constitution responsibility of investigating MDAs in accordance with section 88 and 89 of the amended 1999 Constitution of the Federal Republic of Nigeria. However, 64\% of the respondents submitted that oversight functions have not been able to reduce corruption in MDAs in Nigeria. $88 \%$ of the respondents agreed that capital budget performance has been poor in MDAs since 1999 and $80 \%$ of them agreed that corruption is one of the major factors responsible for poor budget performance of MDAs in Nigeria (See table 3).

Table 3: Responses on the Relationship between Legislative Oversights and Budget performance

\begin{tabular}{|l|l|l|l|}
\hline $\mathrm{S} / \mathrm{N}$ & Responses & Agreed (\%) & Disagreed (\%) \\
\hline
\end{tabular}


Legislative Oversights and Budget Performance in Nigeria: Issues \& Policy Options

\begin{tabular}{|c|c|c|c|}
\hline 1. & Legislative committees conduct oversight functions on MDAs annually. & 90 & 10 \\
\hline 2. & $\begin{array}{l}\text { Legislative oversights have not been effective in enhancing budget } \\
\text { performance of MDAs in Nigeria }\end{array}$ & 85 & 15 \\
\hline 3. & Capital budget performance has been poor in MDAs since 1999 & 88 & 12 \\
\hline 4. & $\begin{array}{l}\text { Corruption is one of the major factors responsible for poor budget performance of MDAs } \\
\text { in Nigeria }\end{array}$ & 80 & 20 \\
\hline 5. & $\begin{array}{l}\text { Most oversight committees are not involved in MDAs budget process: formulation, } \\
\text { implementation, evaluation, etc. }\end{array}$ & 68 & 32 \\
\hline 6. & $\begin{array}{l}\text { Oversight function have not been able to reduce corruption in MDAs in } \\
\text { Nigeria }\end{array}$ & 64 & 36 \\
\hline 7. & $\begin{array}{l}\text { Most members of oversights committees do not have adequate information base on budget } \\
\text { performance of MDAs in Nigeria }\end{array}$ & 67 & 33 \\
\hline 8. & Most MDAs do not have the requisite knowledge of budget implementation & 69 & 31 \\
\hline 9. & $\begin{array}{l}\text { Legislative oversight can be utilized as a vehicle for reducing corruption in MDAs in } \\
\text { Nigeria }\end{array}$ & 90 & 10 \\
\hline 10 & $\begin{array}{l}\text { Legislative oversight can also be utilized as a vehicle for enhancing budget performance in } \\
\text { Nigeria }\end{array}$ & 95 & 05 \\
\hline
\end{tabular}

Source: Author's computation from questionnaires and interviews

Furthermore, $67 \%$ of the respondents agreed that most members of oversights committees do not have adequate information base on budget performance of MDAs in Nigeria, just as $64 \%$ of them believed that most oversight committees are not involved in MDAs budget process especially in the areas of budget formulation, implementation, evaluation, etc. Although, $69 \%$ of the respondents believed that most MDAs do not have the requisite knowledge of budget implementation, but over $90 \%$ of them agreed that legislative oversight can be utilized as a vehicle for reducing corruption and accelerating budget performance in MDAs in Nigeria. Figure 4 shows the responses of the respondents interviewed on the relationship between legislative oversights and budget performance.

Figure 4: Responses on Legislative Oversights and Budget performance in Nigeria

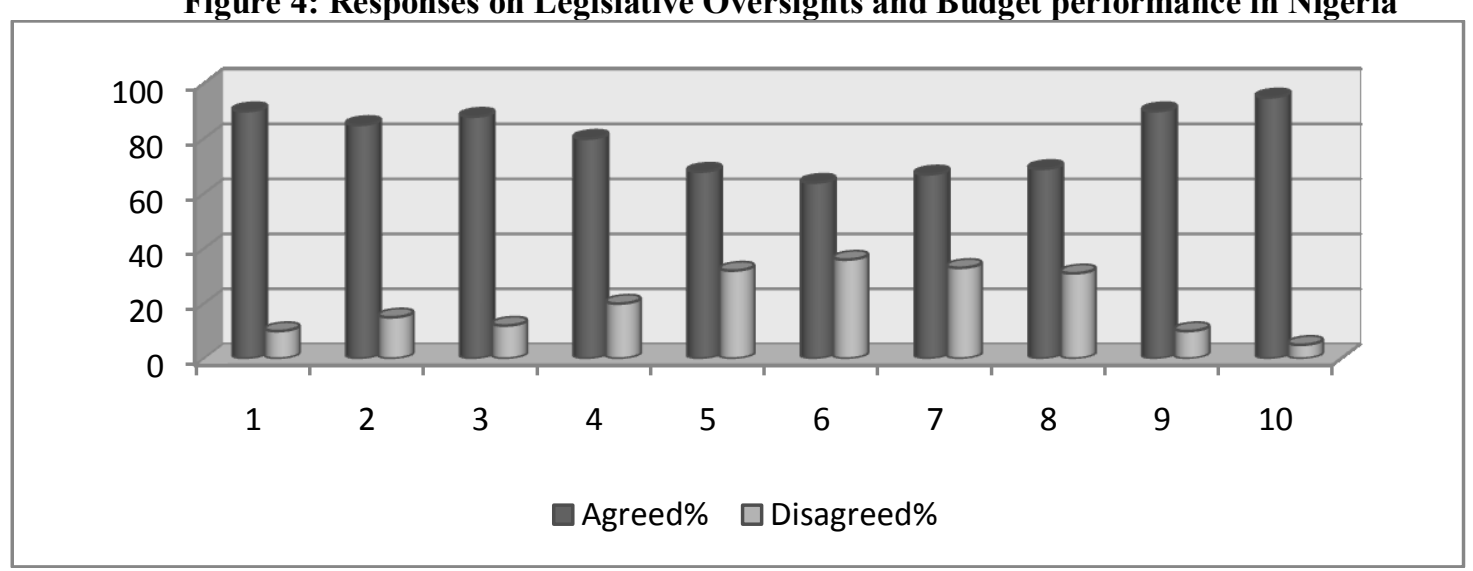

Source: Authors' computation

\section{Findings And Policy Implications Of The Study}

From the analysis of the primary and secondary data gathered through interview and questionnaires, the paper discovered the following; Firstly, it was discovered that legislative oversights are conducted annually on Ministries, Departments and Agencies (MDAs) since 1999 in Nigeria, and these oversight functions have increased tremendously during the period. This implies that the parliament have been carrying out oversight functions on the executive arm of government as stipulated in Sections 88 and 89 of the Amended 1999 Constitution of the Federal Republic of Nigeria. Therefore, it has become a norm for MDAs to welcome oversight committees every year in Nigeria.

Secondly, it was found out that the performance of capital budget has been poor in Ministries, Departments and Agencies (MDAs) since 1999 in Nigeria. This implies that every year the Federal government continues to appropriate funds for capital projects, and these projects are either never executed or poorly implemented by the executive arm of government. The implications of poor budget performance include; high rate of poverty, unemployment, income inequality, infant and maternal mortality and decay in infrastructure. Others are inadequate supply of electricity, water, housing, health, transport and educational facilities.

Though, legislative oversights have been regular in Nigeria since 1999, but they have not been very effective in promoting budget performance. Hence, the predominance of poor capital budget implementation by Ministries, Departments and Agencies (MDAs) in the country. Oversight functions are expensive to embark upon by the parliament because of the resources needed which include; time, financial, human and material resources. It 
would amount to waste of time and resources if oversights do not achieve its purpose of accelerating economic development through the minimization of corruption and the maximization of budget outcomes. This will make the annual budget to become a mere ritual instead of being an instrument for delivering the dividends of democracy to the people.

Fourthly, it was further discovered that corrupt practices are endemic in Ministries, Departments and Agencies (MDAs) and this contributes to the preponderance of poor capital projects implementation in Nigeria. Furthermore, the study also found out that the parliament through oversight functions is not doing enough to expose corruption within the Ministries, Departments and Agencies (MDAs). The implication of this finding is that most of the funds appropriated for projects that would have transform the lives of the people would end up in private hands because most public officers would continue to convert public funds to their private use with impunity since there are no effective checks and balances from the legislative arm of government through oversights.

In addition, the study revealed that some oversight committees do not have the desired information base for effective and efficient oversights and some committee staff do not have the adequate requisite skills, expertise and administrative capacity in budget monitoring and evaluation. Finally, it was discovered that most oversight committees are not involved in the complete budget cycle. Apart from budget approval or enactment, most oversight committees are not involved in the preparation, execution, implementation and evaluation of the budgets of MDAs under their supervision. If most of the oversight committees are not involved in the preparation, implementation and evaluation of the budgets of the MDAs under their supervision, the potency of their oversight will be stumpy. Oversight functions will be more effective if the committees are well involved in the entire budget process as this will make them have access to all the useful information during budget appraisal.

\section{Policy Options And Conclusion}

The policy options for Nigeria based on the findings and policy implications of the study are as follows; Given that many MDAs are supervised annually by the parliament through oversights, there is the need for the parliament to be consistent in their activities. There is the need for routine oversight visits and investigations into the activities of Ministries, Departments and Agencies (MDAs). Oversight functions should be strengthened and carried out more purposefully, regularly and consistently to determine the level of budget implementation.

Also, since inadequate information base hinder oversight functions, it is therefore recommended that more information or data base should be maintained by parliamentary committees to enable them perform their functions effectively and efficiently. There is also the need to strengthen the relationship between oversight committees and the MDAs under their supervision. This will ensure that the committees are consulted and involved during budget preparation, formulation, implementation, monitoring and evaluation. This will help to ease oversight activities and promotes budget performance.

In addition, it was discovered that legislative oversight can be utilized as a vehicle for corruption minimization and budget outcomes maximization in Nigeria. Consequently, to ensure accountability and transparency in the management of public funds, the parliament needs to use oversight as one of the major weapons to ensure that the Appropriation Act as passed by the parliament is well executed by the executive. If well managed, oversight is capable of exposing corrupt practices in public offices and accelerates the implementation of the budgets of MDAs.

Furthermore, it is also important for oversight committees' members to be more transparent and accountable in the performance of their oversight activities if they are to reduce the widespread corrupt practices in MDAs after all, he who must come to equity must come with clean hands. Any corrupt public officer discovered by the parliament during oversights should be immediately handed to anti-corruption agencies such as the Economic and Financial Crime Commission (EFCC), Independent Corrupt Practices and other related Offences Commission (ICPC) and the Nigerian Police Force for prosecution. This will immensely help to expose and reduce the scourge of corruption among public office-holders in the country.

Furthermore, there is the need to train the administrative heads of MDAs and oversight committees' members and staff on budget formulation, preparation, implementation, monitoring and evaluation with a view to ensuring that budget outcomes are achieved. If the parliamentary committees are to get the co-operation from the general public, there is the need to make public the results of oversight investigations into the activities of MDAs. This will enable the general public to help parliament to monitor the capital projects in their areas to ascertain the implementation status and feed the legislature with information necessary for effective oversights.

\subsection{Conclusion}


The paper examined the role of legislative oversights in budget performance of Ministries Departments and Agencies (MDAs) in Nigeria. Using survey method, descriptive statistics, and analytical approach, the study revealed that though oversight activities have increased in recent times, but their effectiveness in promoting targeted budget outcomes have been negligible. Consequently, corruption and poor budget implementation still permeate the spheres of MDAs. The implications of poor capital projects implementation include; high rate of poverty, unemployment, income inequality, infant and maternal mortality and decay in infrastructure, inadequate supply of electricity, water, housing, health, transport and educational facilities. The paper, therefore, posited policy options for Nigeria on how to effectively utilize oversight activities to accelerate budget performance of MDAs in Nigeria.

\section{References}

[1]. Cole, L. \& Brand, S. M. (2011). Congressional Investigations and Oversight: Case studies and Analysis. Caroline Academic Press: Durham, North Carolina.

[2]. Corder, Hugh (1999). Report on Parliamentary Oversight and Accountability. Prepared by the Law Faculty of the University of Cape Town. October, 18.

[3]. Dorotinsky, William \& Yasuhiko, Matsuda (2002). 'Reforma de la gestión financiera en América Latina: Unaperspectiva Institucional,' Reforma Democracia 23:141-166.

[4]. Griffith, Gareth (2005). Parliament and Accountability: The Role of Parliamentary Oversight Committees. Revised version of a discussion paper prepared for the ASPG Conference on Parliament and Accountability in the 21st Century. Sydney, 6-8 October.

[5]. Hubbard, Rutherford (2012). Need for Parliamentary Oversight for Governance and Accountability. Daily FT, February 15.

[6]. Kuruppu, C. \& Gårseth-Nesbakk, L. (2012). Accountability Limitations with respect to Parliamentary Oversight: A case of Norway and Sri Lanka, Bodo Graduate School of Business University of Nordland 8049 Bodo, Norway.

[7]. Langdon, Steven (2012). Parliamentary Oversight as a Mechanism for Accountability

[8]. Lienert, I. (2009) Legislative Oversight and Budgeting - A World Perspective.

[9]. Mainwaring, Scott and Christopher, Welna eds. (2003). Democratic Accountability in Latin America (Oxford: Oxford University Press)

[10]. Mill, J.S. (1861). Considerations on Representative Government. London: Parker, Son, and Bourn.

[11]. Nakamura, R.T (2008). Legislative Oversight and Budgeting. Joint-Bank Fund Library, World Bank

[12]. O'Donnell, Guillermo (2003). Horizontal Accountability: The Legal Institutionalization of Mistrust, in Scott Mainwaring and Christopher Welna, eds. Democratic Accountability, 34-54.

[13]. Obayuwana, O. (2012). Legislative Oversight: The Executive Arm at a Crossroads.

[14]. Onyekpere, E. (2012). Legislative Oversight and the Budget. Punch Newspaper, November 26.

[15]. Pelizzo, Riccardo \& Stapenhurst, Rick (2004). Tools for Legislative Oversight: An Empirical Investigation (Washington, DC: World Bank Policy Research Working Paper 3388).

[16]. Santiso, C. \& Belgrano, A.G (2004) Legislative Budget Oversight in Presidential Systems: Governance of the Budget in Peru. Paper prepared for the XVI Regional Seminar on Fiscal Policy, Santiago de Chile, 26-29 January.

[17]. Santiso, Carlos (2005). Budget Institutions and Fiscal Responsibility: Parliaments and the Political Economy of the Budget Process in Latin America. World Bank Institute Washington, D.C.

[18]. Schedler, A., Larry, D. \& Marc, P. (1999). The Self-Restraining State: Power and Accountability in New Democracies (Boulder: Lynne Rienner.)

[19]. Stair-Hall, Grand (2011). Legislative Oversight: A Guidebook for Ohio Legislators. Ohio Legislative Service Commission.

[20]. Stapenhurst, Rick (2012). Good Governance, Parliamentary Oversight and Financial Accountability: Parliamentary Consideration Of The Budget. World Bank Institute.

[21]. Warren, K \& Joachim, W. (2004). Legislatures and Budget Oversight: Best Practices. Paper Presented at the Open Forum held by Kazakhstan Revenue Watch in Almaty on April 8.

[22]. Warren, Krafchik, (2003). What Role Can Civil Society and Parliament Play in Strengthening the External Auditing Function? Paper was presented at an African regional workshop, Towards Auditing Effectiveness, organised by the World Bank Institute, Ethiopia 12-15 May.

[23]. Wehner, J. \& Warren, K. (1998). 'The Role of Parliament in the Budget Process,' South African Journal of Economics 66(4):512541.

[24]. Wehner, Joachim (2004). Back from the Sidelines? Redefining the Contribution of Legislatures to the Budget Cycle (Washington, DC: World Bank Institute Working Paper.)

[25]. Woodrow, W. (1885). Congressional Government. Boston: Houghton Mifflin p. 297

[26]. Williams, J.G (2012). Parliamentary Function of Oversight 